\title{
Introducing a New Idea: Severance of Public Parking in Iran
}

\author{
Masoud Maasoumi ${ }^{1}$ \\ ${ }^{1}$ Official Officer of Iranian Judgment Ministry In Urban Planning Branch, Tehran, Tehran, Iran \\ Correspondence: Masoud Maasoumi, Official Officer of Iranian Judgment Ministry In Urban Planning Branch, \\ Tehran, Tehran, Iran. E-mail: m_masoumi33@yahoo.com
}

Received: July 8, 2017

Accepted: July 22, 2017

Online Published: August 29, 2017

doi:10.5539/mas.v11n9p131

URL: https://doi.org/10.5539/mas.v11n9p131

\begin{abstract}
In 1902, Mozafaredin Shah was familiar with the car on his trip to Europe and brought two cars to Iran. Gradually more cars were brought into the country. Since 1921, the body of Iran's major cities was affected by movement of vehicles. Nowadays, the unbridled use of cars affects Iran's urban management, particularly in cities with a population of more than fifty thousand persons. In addition to the many advantages, the vehicle presence in Iranian cities sometimes has negative consequences. Traffic, noise and air pollution are inevitable disadvantages. Lack of public and private parking is a serious issue for those involved in planning and urban management in Iran, leading to social and economic costs. Lack of parking in Iranian cities is affected by cultural and economic factors and administrative structures. The creation of public parking will not be improved without modification of the factors. Hence, this study introduces a new idea based on the reform approach which resolves a significant part of the problems. This idea is based on the revision and reform of registration rules. A corrective action in the event of operational supports leads to improving the construction of public parking. This new idea provides the severance of public parking and the possibility of issuing the entire document for each unit of parking.
\end{abstract}

Keywords: parking, public parking, severance, entire document, deteriorated urban areas

\section{Introduction}

The arrival of cars to Iran dates back to a hundred years ago. Mozaffareddin Shah Qajar brought the first car to Iran and the royal family gradually increased the number of cars in big cities. Streets were deformed for vehicle movement in the capital of Iran (Tehran) and a few cities. Modification for street network was first performed in Tehran and then in some cities, such as Hamadan, Kerman, Isfahan, etc. The first map of urban changes, known as "street map" was prepared in 1922 and it was implemented in 1934. The modification design was inspired by the Haussmann design method in Europe in the 1920s (Rahnamaei and Shah Hosseini, p. 57).

Nowadays, the rate of car ownership as a means of personal and public vehicles has increased in urban areas of Iran. Iran manufactures cars and the rate of using has increased significantly. The rate of parking production as a place for the stop of vehicles is lower than the rate of imports and production of cars. Lack of sufficient parking leads to some negative physical, traffic, social, and economic consequences, such as traffic congestion, psychological stress for the citizens and car holders and even the lawsuits in courts because of disputes between the car owners in the street. Some statistics that indicate seriousness of the situation in Tehran for the status and performance of cars in transporting passengers are as follows:

- Tehran is a city with a population of 8.6 million people and an area of 60,000 hectares and average population density of 143 persons per hectare. There are 41 cities near Tehran, which have the daily traffic volume with Tehran.

- Impact assessment of traffic for a variety of vehicles during peak hours in Tehran in 2013 based on the type of vehicle is as follows: motorcycles $(9.8 \%)$, cars and vans $(71.5 \%)$, bus $(0.9 \%)$, taxi $(14.4 \%)$ and other $(3.4 \%)$. (Statistics on Tehran, Traffic \& Transportation, p. 4).

- The number of daily trips within the city during three time periods is as follows: 14.6 million per day in 2004; 17.4 million per day in 2012 and 17.7 million per day in 2013. These trips were for purposes of employment, education, shopping, recreation, etc.

- Tehran has 14 main entry and exit routes (e.g. highways of Karaj and Saveh, roads of Lavasanat, Khorasan, 
etc.). In the morning peak hour, a total number of 63 thousand trips were recorded for entry and exit routes of Tehran in 2013.

- In 2013, the average daily number of 12548 incoming passengers and 13653 outgoing passengers using railway was recorded for Tehran city (other than urban subway network) (Statistics on Tehran, Traffic \& Transportation, 83).

- A total of 18 million trips a day and 5.15 million transportations are estimated in Tehran's street network for the horizon of 2025 . Thus, it is predicted that trips are done as follows: $25 \%$ by private vehicles, $30 \%$ by urban railway, $22 \%$ by buses, $3 \%$ by minibuses, and $20 \%$ by taxi (Mousavian, Abolhasan pp. 12-14).

- In 2013, there were a total number of 15 thousand smart roadside parking and 2400 traffic wardens (transportation industry, No. 332, pp. 54-56). This number of roadside parking is very low for a big city, such as Tehran.

The above statistics indicate a greater share of urban travel by cars and generally express the volume of traffic in Tehran. This volume of traffic, especially significant share of cars and passenger transportation, requires precise planning and management. One of the basic requirements is the provision of parking for cars; thus, the presents study investigates this issue.

\section{Method}

The main objective of this study is to explain the problems caused by the lack of public parking for cars in Iranian urban population as well as propose a new idea based on the guidelines and registration laws in Iran. Therefore, each unit of public parking (vertical or horizontal, other than mechanical) is divided by the Real Estate Registration Department and the entire document is issued for it. Drastic changes are made in the issue of building a public parking and a substantial part of the problems is solved or reduced.

It should be mentioned that I proposed design and implementation of public parking and formulating a guideline for severance of parking and issuing an entire document for each unit in Tehran Province. Real Estate Registration Office of Tehran Province accepted my proposal and it was implemented in some cities of the province as a pilot project. However, it has not been investigated at the ultra-provincial level scientifically. Hence, this study investigates the new idea.

\subsection{Classification of Land Use and Parking in Iran}

Iran's Supreme Council for Planning and Architecture as the most professional decision making body for urban planning and architecture defined the city's per capita and a variety of land uses for the first time in 2010 . According to the act passed by Iran's Supreme Council for Planning and Architecture on 2010/05/31, the urban land uses are classified into 20 types: Residential, training, service, transportation and warehousing, etc. (Iran's Supreme Council for Planning and Architecture, p. 833). The minimum and maximum per capita was defined for each of these land uses. In addition, the permissible activities were determined for each land use. No particular per capita rate was determined for public parking. A total of 30 square meters or more was determined for the use of passages, terminals, warehousing, and transportation in cities (Council for Planning and Architecture, p. 848).

There are different types of classification for parking based on ownership, the extent of performance, and structural and architectural characteristics. In terms of the extent of performance, it is divided into neighborhood, regional, urban, and extra-urban. In terms of the structural and architectural characteristics, it is divided into single-level covered parking, non-vertical single-level parking, and vertical mechanical parking. In terms of ownership, it is divided into dependence on government, dependence on municipality, private, public, and endowed.

\subsection{Major Challenges in the Construction and Maintenance of Public Parking in Iran}

Major challenges in the construction and maintenance of public parking in Iran are as follows:

1) The delay in understanding the importance of the construction of public parking in Iran:

- According to the current legislation and resolutions of the Council of Ministers, assistance has been offered to finance and construct a variety of buildings with the use of services (such as education, health, urban green space, passageways, etc.). However, creating public parking has not been emphasized by legislators and the Council of Ministers, and this issue has been insignificant among laws and legislations in the past decades. According to Note 5 under Article 100 of the Municipal Act, amended on 1979/09/18, Commission of building violations can consider a fine of at least 1 and at most 2 times the value of building for each square meter of the lost space of the parking. According to this note, the parking area is equal to 25 square meters (Mansour, Jahangir, p. 395). It should be noted that this article of the law does not consider 
the creation of public parking and emphasizes that lack of car parking is negligible in possible conditions. According to Article 55 of the Municipal Act, municipal tasks include creating streets, squares, electrical and water installations, building and maintenance of public parks and gardens, etc. However, creating public parking is not considered. The importance and necessity of creating public parking are not considered in five-year plans for Iran's economic and social development. According to Article 117 of the fourth development program law (2005-2009), the Department of housing and urban planning must consider the importance and necessity of buying land uses for sports. However, the land use for car parking is not considered.

- $\quad$ Since the beginning of 1921, the organic body of cities has changed by vehicle traffic, but the creation of public parking has not been considered. Urban management and even the private sector have focused on the widening of existing passageways and building new passageways. Recently, municipalities in major cities have taken measures for creating parking because of social pressures arising from the lack of parking. However, the speed of operation is not enough, and only a very small part of the problems will be reduced.

- Urban development plans (comprehensive plans, etc.) were approved on the basis of the views and decisions of the Iran's Supreme Council for Planning and Architecture and implemented by the municipalities. They had no evaluation for profit and cost, phasing, and executable programs. Not only public parking, but also other land uses had a very low realization factor because of some financial shortages. Thus, a small part of the plan was implemented and public parking was excluded.

2) Lack of comprehensive plans to create public parking in cities.According to the Interior Ministry's Circular No. $2331 / 1 / 3 / 34$ on 1992/04/27, municipalities are required to create public parking based on fines and tax received from the owners. However, it has not been implemented in Tehran province. Municipalities often spend the revenues from this circular on other sectors, except for creating public parking. Municipalities and city councils have no significant tendency to creating public parking and rarely show interest in formulating and implementing plans for creating public parking.

3) There's no economic justification for builders to construct the public parking in cities of Iran because of land prices and other indicators in the current situation. In 2013, if Tehran Municipality gave maximum loan to the builders of parking; the price per unit of parking would become at least 100 million Rials. The monthly revenue per unit was estimated about 2 million Rials. However, the profit rate for 100 million Rials was far higher in other businesses (transportation industry, No. 332, pp. 54-56). This disproportion is still true for the construction of rented parking. It should be noted that the public parking tariff is the same for all kinds of vehicles. For example, the same tariff for very cheap cars is received for very expensive cars. However, having parking for the very expensive car owners is far more important than others. In the current situation, severance of public parking is impossible and it is possible to buy and sell the whole building at once and generate revenue through hourly, monthly, and seasonal rent to car owners.

4) Tehran Province has 42 urban points. The area of comprehensive plans in this province is 660,832 hectares. 6031 hectares of this area (about 10 percent) is considered as deteriorated areas. Considering the 60,000 -hectare area in Tehran, about 3268 hectares consist of deteriorated areas which are the basic problems for urban planners and managers. These areas cannot be used as the car parking because of some restrictions.

\section{Problem Statement}

The main problem in this study is the severance of commercial, administrative, service buildings in Iran and issuing the entire document. There is no law article and guidelines for severance of public parking to issue the entire document for each unit. In the event of severance, each unit can have a separate owner and can be bought and sold, leading to psychological and economic incentives for construction. Some lawyers believe that the absence of formulation and adoption of a law article on severance of public parking does not imply the prohibition. For the author of the present study, this issue is ambiguous in Iran and failure to do this process in the current situation and in the past decade implies lack of operational procedures for it because there is no successful experience in Iran.

It is noteworthy, in spite of no legal prohibition, severance of public parking is not common in Iran.

\section{Foundation and Theoretical Framework}

The use of private cars is increasing in Iran. There is one car per 175 inhabitants in Iran. (Khaksari, Ali. p. 43). The car is not constantly moving in streets, but has temporary stops for several hours. Considering the ramp, turning radius, etc., 25 square meters is needed for parking a car. The owner is responsible for the supply of parking and paying a fine for lack of parking. Although the car was brought into Iran in 1902, the physical 
changes in organic fabric of Iranian cities have begun with a 20 -year delay. The changes are associated with widening, creating, and modifying streets, and construction of public parking has not been considered so far. Iranian laws have not seriously considered providing car parking. Providing car parking has not been considered in a variety of urban development plans beginning by the Ministry of Interior in 1962 and continuing by the Ministry of Development and Housing (Note 1) In most urban development plans, there is no incentive criterion to create public parking. Iran's Supreme Council for Planning and Architecture has not approved a specific criterion based on conditions for the development of public parking.

In the past, different types of buildings were required to guarantee the minimum for parking in most parts of the world. For example, owners of residential buildings were required to create at least one parking space for each residential unit. In Iran, some standards based on the regulations of urban development plans are considered for the parking space in commercial, residential, and administrative uses.

In the cities of Tehran province using urban development plans, providing at least one parking space is required for each residential unit. For residential units greater than 100 square meters, more parking spaces are required; for example, providing one and a half parking spaces for residential units greater than 150 square meters. For every 100 square meters of commercial units, three parking spaces are required.

It might be interesting for Iranian readers that European cities have outdated the minimum parking requirements for residential uses and have determined the maximum parking requirements for some uses. In addition, Paris has outdated the minimum parking requirements for residential uses and some cities have determined the maximum parking requirements in different zones (Report 147, p. 17). In many parts of the world, there is a significant reduction in the supply of personal transportation infrastructures, such as parking. Therefore, some standards have been determined for providing parking based on use attributes, access to major public transport corridors, etc.

In Hong Kong, the space for parking for commercial uses in downtown areas is between zero and the minimum permissible parking space. In spite of high per capita rate for car ownership in Tokyo, 0.5 units per 100 square meters are considered for parking spaces of commercial buildings.

Providing new parking was banned in Zurich in 1996 and in Hamburg in 1976. For creating each unit of the non-roadside parking space, one unit of the non-roadside parking space is removed to remain constant the parking lots in Zurich (Report 147, p. 16). The construction permit for parking is issued for spaces that the streets have the capacity to attract traffic so that they create no traffic problems, pollution and nuisance.

In the above examples relating to the European countries, the rate of supply and demand for parking has been studied and the number and type of required parking for the entire neighborhood or zone are determine in accordance with the urban fabric and a variety of uses. The standard maximum for parking is to restrict the entry of cars into the neighborhood and blocks. Given the tendency of citizens to private ownership and some other factors in Iran, parking spaces are provided by owners and builders of buildings in Iran. Thus, the parking spaces are sufficient in each building. This standard provides the permission for the vehicle entry to the neighborhood and blocks. As mentioned, Iranian lawmakers approved legislation that fines people for the removal of parking. According to the circular of the Interior Ministry, municipalities are obliged to collect the money for the construction of public parking, but it has not been implemented (Note 2)

It should be noted that European plans cannot be followed exactly in Iran. Investigating the factors and cultural, economic, social and physical indicators helps to understand the current and future situation, and citizens' behavior. Finally, the indicators must be analyzed and a combination of the models is used. Factors, such as the use of a variety of vehicles (bicycles, car, subway, bus, etc.), distance from accommodation to shopping centers, extension of street network, the tendency of people to cars, the price of land, amount of loans, and tariff rate for the construction, etc., are effective in the analysis of situations.

As mentioned earlier, Tehran has deteriorated urban texture. According to the act passed by the Iran's Supreme Council for Planning and Architecture on 2006/05/01, deteriorated urban texture is the texture requiring modernization and improvement. Indicators of deteriorated urban texture are as follows: more than $50 \%$ of the blocks in the texture have no structural stability; more than $50 \%$ of the blocks in the texture have street width less than $6 \mathrm{~m}$; more than $50 \%$ of the blocks in the texture have an area less than 200 square meters (Iran's Supreme Council for Planning and Architecture, p. 623) (Note 3). It should be noted that providing parking inside the deteriorated urban texture is basically impossible and unreasonable. Cars cannot enter the deteriorated urban texture because there is not enough space for the design and implementation of car parking. Obviously, if the streets are widened, the lots will become smaller and the provision of car parking will be more difficult. Therefore, there cannot be the public parking in these neighborhoods. 
The urban tissue age is more than 30 years' old that is the period of time when the urban development plans were not approved in most cities and legal proceedings for investigating the construction violations did not begin and owners were not fined for the removal of the parking space. After three decades, people have financial ability to buy a car now. Thus, providing the car parking inside buildings is based on early and forced demolition and renovation by owners. Obviously, imposing tastes is not welcomed by owners and demolition and renovation (only to provide car parking) seems to be uneconomical.

Demolition and renovation of some urban textures must be prevented to maintain the historic-cultural values. The old textures have historical values. In addition, urban textures of ramps more than 30 degrees have historical values.

The price of land in the commercial - administrative textures is very high and buildings overlooking the street have commercial and profit uses. It is natural that the edges and all volumes are used to create showcases, exhibitions, etc. The underground floors are used for ancillary activities, such as production and storage. In case of providing the car parking, the allocation of high-value lands along the ground floor and the top floor for parking does not seem logical and economical.

Urban planners suggest that the design of the car parking cannot be implemented inside buildings and should be built outside of the blocks with the appropriate access distance. It is suggested the public parking is designed and implemented in the back blocks and away from the commercial units.

\section{Definition of Severance}

Severance means dividing the different parts of an estate. In the case of apartments in a residential complex, severance means determining the scope and location of each apartment and the area without taking into account the contribution of each partner (Ebrahimi Ghajar, Shahrokh, p. 59). Severance refers to dividing land into a number of individual lots and issuing the entire document for each lot by the Real Estate Registration Department. In Iran, severance refers to dividing a building (commercial, administrative, and residential) into several units.

\section{Definition of Severable Public Parking}

For the author, the characteristics of the severable public parking are as follows:

- The land use in the urban development plan and the building permit are announced for the public parking.

- After determining the scope and location of the parking and the area of each unit, the entire document is issued to provide the conditions for buying and selling of each unit in Iran. Obviously, this type of severance includes land. After deduction of parking, ramps, corridors, stairs, lifter area, etc. are considered as common parts.

- In general, severance of the mechanical parking is illegal in terms of registration laws in Iran because it is considered as the movable property and cannot be separable.

\section{Introducing the New Idea}

The new idea of this study is that providing the car parking inside buildings should not be imposed on owners. Urban planners in Iran should accept that providing the car parking inside buildings is non-normative and non-economic. Public parking complexes can be established and each unit is separated to issue the entire document for it.

According to this idea, one of the reasons for lack of the public parking construction in Iran is lack of economic justification. Lack of economic justification in the current situation is due to the impossibility of severance. This method has a very small income compared to other projects. The income may be less than the bank interest rate in Iran (20 percent annually). Thus, the government, municipalities and private sector investors are not interested in investing in these projects.

For the author, preparation and the possibility of severance, and removing the above restrictions lead to the investment boom in these projects. In Iran, any property (residential, commercial, and gardens) is considered as the product and follows the laws of supply and demand. Residential and commercial uses are considered as the main use and the car parking is considered as the service use dependent on the main use. In other words, the car parking is part of housing and commercial facilities, as the living room is part of housing facilities. There should be the same rules and procedures for the main use and parking in order that the number of residential and commercial units is proportional to the car parking. Freedom of transfer for residential units cannot be recognized and public parking lots are managed through hourly rental. 
The severance of commercial, administrative, service buildings (other than public parking) in Iran is common. There is no law article and guidelines for severance of public parking to issue the entire document for each unit. In the event of severance, each unit can have a separate owner and can be bought and sold, leading to psychological and economic incentives for construction. Residential or commercial units can be linked to the parking lot a few hundred meters away. Purchasing the parking a few hundred meters away by the owner can be considered as providing the parking. Thus, the owners are not fined for the lack of the parking. Consequently, the number of cases related to building violations is reduced in the commission of article 100 of municipalities act and the court of administrative justice.

Considering the above conditions and challenges, the author suggests some prerequisites to operate this new idea as follows:

- Constructing different types of the parking (such as smart roadside parking, vertical parking, and covered parking) should be based on the needs of the city and neighborhoods around the city. In other words, there must be a balance between supply and demand.

- It is necessary to reform the laws of registration of property documents in Iran and the formulation of a specialized approach to ease restrictions for issuing the entire document.

- Performance of the parking should be followed as an indicator of inspection systems and performance evaluation in the executive agencies and municipalities.

- It is necessary to explain the importance of the issue for the authorities, city managers and especially the city council to grant some exemptions and installment payment for a project to create the public parking. Obviously, the removal of attractiveness for the car parking inside the building encourages owners to construct the public parking.

- Iran's Supreme Council for Planning and Architecture should formulate regulations for the construction of different uses. Part of the car parking space is allocated to meet the costs of creating and maintaining profitable uses, such as commercial and service uses. Thus, the public parking space is out of rough. The commercial edges should be developed on the underground first floor and the ground floor because pedestrians have the appropriate horizontal visibility.

\section{References}

Department of planning for information and communication technology in ministry of roads and urban development. (2014). Statistical yearbook of road transportation in 2013. The eighth day publications.

Ghajar Ebrahimi, Shahrokh. (2012). A Book for Official Experts of Justice. Tehran: Shadrang Publications.

Iran's Supreme Council for Planning and Architecture (2012). The Approvals Iran's Supreme Council for Planning and Architecture (from inception to the end of 2011). Publications of Secretariat of the Supreme Council for Planning and Architecture, Tehran, Iran.

Kamalan, Seyed Mahdi. (2007). Real Estates Registration Act. Tehran: Kamalan Publications.

Khaksari, Ali. (2014). Urban transportation with an emphasis on social aspects. Publications of department of transportation and traffic in Tehran.

Mansour, Jahangir. (2005). Fourth program law for economic, social and cultural development of Islamic Republic of Iran. Tehran: Agah Publications.

Mansour, Jahangir. (2007). Laws and regulations related to the province, city, town, village and municipalities. Tehran: Didar Publications.

Mousavian, Abolhasan. (2013). Metro-based development model for urban public transportation. Journal of Transportation Industry, 324, 12-14.

Rahnamaei, Mohammad Taghi., and Shah Hosseini, Parvaneg. (2008). The process of urban planning in Iran, Tehran.

Research Center for Tehran Urban Planning. (2012). Organizing strategies for roadside parking in neighborhoods, Report No. 147, management of information technology and documentation center.

Saeidi Nia, Ahmad. (2011). Urban plans in Iran. Organizations for municipalities and rural affairs, Tehran.

The absence of private sector in the development of public parking. (2014). Journal of Transportation Industry, $332,54-56$.

Transportation and Traffic Department of Tehran Municipality. (2014). Statistics of transportation and traffic in Tehran in 2013. Company of transportation and traffic studies in Tehran. 


\section{Notes}

Note 1. The beginning of preparing urban development plans in Iran dates back to about 1962. The preparation of urban development plans with physical aspects began in the Ministry of Interior. The Ministry of Housing and Urban was established in 1964. Iran's Supreme Council for Planning and Architecture was established in 1972 and all kinds of comprehensive plans were prepared (Saeidi Nia, p. 19).

Note 2. In Iran, legislation passed by Parliament is at a higher level of the resolution of council of ministers and Iran's Supreme Council for Planning and Architecture. Circulars are issued by ministries and executive agencies and the approvals of the government and supreme council are at a lower level than legislation passed by Parliament.

Note 3. Indicators of deteriorated urban texture approved on 2006/05/01 are under review by the Iran's Supreme Council for Planning and Architecture and some indicators, such as per capita income, poverty, etc., have been considered to determine the deteriorated urban texture.

\section{Copyrights}

Copyright for this article is retained by the author(s), with first publication rights granted to the journal.

This is an open-access article distributed under the terms and conditions of the Creative Commons Attribution license (http://creativecommons.org/licenses/by/4.0/). 